\title{
ANALYSIS OF MICRTOIC E-MODULE TRAINING DEVELOPMENT NEEDS
}

\author{
Khairul Anshari ${ }^{1}$, Kasman Rukun ${ }^{2}$ and Asrul Huda ${ }^{3}$ \\ ${ }^{1}$ Graduate Program of Vocation Technology Education Faculty of Engineering, \\ Universitas Negeri Padang, Indonesia \\ ${ }^{2}$ Lecture Faculty of Engineering, Universitas Negeri Padang, Indonesia \\ ${ }^{3}$ Lecture Faculty of Engineering, Universitas Negeri Padang, Indonesia \\ Email: anshari_khairul@yahoo.co.id
}

*Corresponding Author, Received: November 12, 2019, Revised: December 10, 2019, Accepted: December 21, 2019

\begin{abstract}
The purpose of this study is to conduct a needs analysis for the development and compilation of e- modules. The e- module was prepared to facilitate training in order to improve the competency of informatics engineering teachers in West Sumatra. The development of e- module is using the model ploom and nieveen . The development procedure consists of 3 stages, namely 1) preliminary Research 2) prototyping stage and 3) assessment phase. Research carried out in the period 6 months, to perform the analysis of the needs in some of SMK Negeri Sumatra west who have majors engineering informatics and designing e- module training. Subject of research is the teacher engineering informatics SMK Negeri that exist in West Sumatra. Analysis of the data is done by descriptive with the method of the survey. From the results of the analysis obtained that . From the results of the analysis obtained that Master requires a time that is free to carry out training so as not interfere with the process of learning to teach. Second of all teachers in need of training in the field of competence of each , such as in the field of engineering of computer networks, teachers require training on connecting cable fiber optics, build networks, administer the network and use mirotik and Cisco. Teachers also need the latest developments from the 2013 curriculum, namely materials, modules and teaching materials.
\end{abstract}

Keywords : : Requirement Analysis, Competence, Training

\section{INTRODUCTION}

Education is very important for the life of mankind, even guaranteed by the state so that with education we have a better life in the future, with education will improve the quality and degree of human life that affects the quality of the nation and 


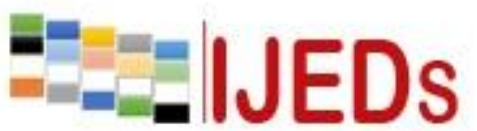

http://ijeds.ppj.unp.ac.id/index.php/IJEDS
International Journal of Educational Dynamics

Vol. 2 No. 1 (pp. 77-83) Desember 2019

p_ISSN 2655-4852

e_ISSN 2655-5093

state. This is in accordance with the mandate of Law No. 20. Year 2003 concerning the National Education System which states that, "Education is a conscious and planned effort to create an atmosphere of learning and learning process so that students actively develop their potential to have spiritual spiritual strength, self-control, personality, noble moral intelligence and the skills needed by themselves, society, religion, nation and country".

Education aims to educate the nation's life and one of the determinants of the successful implementation of human resources to improve the standard of living of a nation. Education develops human potential so that they are able to deal with changes in scientific and technological advancements that occur at the present time. Education is the main key to the success of a nation's development, it is hoped that it can become a tool for community empowerment towards more creative, productive and innovative human resources in facing challenges. Education in accordance with the functions and objectives of the education system produces quality human resources and is able to compete in the industrial world. Improving the quality of the process and learning outcomes at every level of education is important to be realized, because it is the duty and responsibility of all parties involved in the management of education including: government, teaching staff and community education.

Vocational education is secondary education that prepares students primarily to work in certain fields. The teacher is a professional educator who has an important task, function and role in educating the life of the nation. Modules are tools or tools used for learning that provide some material or basic components of teaching materials that are processed to facilitate learning. Teacher competency test (UKG) which is carried out, is expected to be used as a means of mapping teacher competencies whose results will be followed up as a reference in teacher development so that teachers have the competence and professionalism expected.

The 2015 National UKG results, obtained a national average of 50.97 from the national target set by the government 55.00. This shows the lack of teacher competence nationally that needs to be improved in order to achieve national learning goals. The $\mathrm{UKG}$ is based on the area of expertise proposed by the teacher. Submissions made by teachers have been based on teacher education background, but specifically in the case 


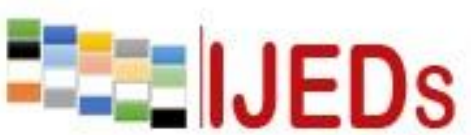

http://ijeds.ppj.unp.ac.id/index.php/IJEDS
International Journal of Educational Dynamics

Vol. 2 No. 1 (pp. 77-83) Desember 2019

p_ISSN 2655-4852

e_ISSN 2655-5093

of informatics engineering teachers, the educational background of Informatics Engineering teachers into three concentrations namely the concentration of Multimedia, Software Engineering and Computer Network Engineering.

Modules are tools or tools used for learning that provide some material or basic components of teaching materials that are processed to facilitate learning. Modules are also teaching materials that are processed in a complete, planned, systematic and standalone way to make it easier for students to achieve learning objectives. With modules that are in the form of applications commonly called E-Modules or electronic modules. E-Modules are teaching materials that are prepared and used in the form of applications or electronics that contain subject matter that is compiled in full to help students achieve their learning goals.

The teacher is one of the important components in the teaching and learning process, has a place that greatly determines the success of learning, because the main task of the teacher is to design, manage, implement and evaluate learning. The teacher is a professional educator who has an important task, function and role in educating the life of the nation. In addition, the position of teacher in the implementation of teaching and learning is also very strategic and decisive. One of the factors that influence the success of a teacher's task is his performance in planning or implementing and evaluating teaching and learning. The government and the community have great expectations for teachers. Teachers are expected to be professional and have competence and carry out obligations as educators.

Based on RI Law No. 14/2005 concerning Teachers and Lecturers: "Professionals are work or activities carried out by a person and become a source of income for life that requires expertise, skills or skills to meet certain quality standards and norms and requires professional education".

Professional teachers must meet a number of minimum requirements, including: having appropriate professional education competencies, having knowledge competencies in accordance with their fields, having good communication skills with students, having a creative and productive spirit, having a work ethic and being highly committed to their profession, and always improve the ability to develop themselves 


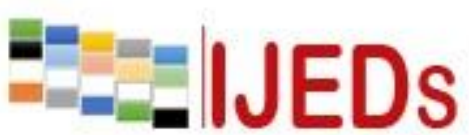

http://ijeds.ppj.unp.ac.id/index.php/IJEDS

continuously (continuous improvement) through organizations, the internet, books, seminars, and the like.

\section{METHOD}

Samples research as much as 132 teachers in the download of 17 SMK Negeri who have majors engineering informatics, areas of expertise engineering computer network (TKJ), engineering tools software (RPL) and Multimedia (MM) are scattered in West Sumatra. Intake sample to the technique is simple random sampling. The collection of data using a questionnaire with some questions that are answered directly on sheet questionnaire. With 13 questions about (1) the development of the competence of teachers, (2) barriers to follow , (3) classification of teachers, (4) utilization after following the training, (5) the obstacles in the implementation in schools , (6) always do the evaluation , (7) evaluation used as a reference , (8) who are doing the evaluation , (9) the obstacles in the implementation of training, (10) training which is very needed future, (11) the institution that never foster the development of competence , (12) methods of assessment are used , (13) responses from the training that followed .

The problem of research is to know shortage of training beforehand, either from the terms of the implementation, of the terms of the materials were delivered, and the need for training of the competency of teachers for the future. The data collected was analyzed by Seed assessment as a gap between what are there and what are supposed to be. In a study of this gap can be interpreted as the difference between the performance should the performance of the real in the field. As well as the training that is required by the teacher for the period of 1 or 2 years in the future.

\section{RESULTS AND DISCUSSION}

Analysis of training needs is carried out after need assessment, by identifying gaps between the competencies that teachers want to achieve through developing competencies and the conditions in their respective schools. Gaps in the competency training that have been carried out are shown in Table 1. 
http://ijeds.ppj.unp.ac.id/index.php/IJEDS

Table 1. Constraints that occur in the field

\begin{tabular}{l|c}
\hline THE PROBLEM & AMOUNT OF RESPONSE \\
\hline Time constraint & 23 \\
Infrastructure constraints & 70 \\
Cost Constraints & 2 \\
Material Constraints & 5 \\
Condition Constraints & 17 \\
No problem & 16 \\
\hline
\end{tabular}

Based on the distribution of needs analysis questionnaires, there are still a number of teachers who have never attended training for the competencies of each department. Of some teachers who never carry out training responding to the results were obtained on the training competence is very useful for teachers and schools, but there are constraints of each maing schools in the implementation of the results of the training competence, such as the constraints of equipment schools are not complete as at the time of training competency. Obstacles more to carry out the training competence is the constraints of time and cost, do not have the cost to implement the training competence of the distance traveled far and cost large. Do not have time to leave teaching and family learning processes that must be left behind in carrying out competency training .

Based on the analysis of the needs of the training which will be implemented in a time close, the teacher requires some training that varies in accordance with the needs of the majors each -masing, the curriculum some teachers require training curriculum K13 and materials for curriculum latest. In the vocational field, each TKJ teacher needs training on Cisco, microtic , fiber optic, network administration, softswitch and IPV6. On teacher RPL requires training on android, Web and Java, while the teacher MM requires training on Graphics, Audio Video, Film, Animation, 2D and 3D. Details about the need for training that takes contained in Table 2.

Table 2. Details of training needs

\begin{tabular}{|c|c|}
\hline NEEDS & $\begin{array}{c}\text { AMOUNT OF } \\
\text { RESPONSE }\end{array}$ \\
\hline Cisco training & 14 \\
\hline Microtic training & 18 \\
\hline Optical fiber installation & 8 \\
\hline Graphic design training & 4 \\
\hline Training makes animation & 6 \\
\hline Film making training & 6 \\
\hline Web creation training & 7 \\
\hline Android programming training & 8 \\
\hline Java programming training & 4 \\
\hline
\end{tabular}




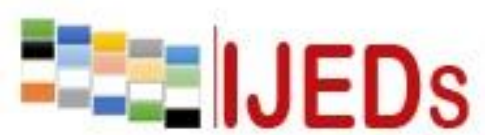

http://ijeds.ppj.unp.ac.id/index.php/IJEDS
International Journal of Educational Dynamics

Vol. 2 No. 1 (pp. 77-83) Desember 2019

p_ISSN 2655-4852

e_ISSN 2655-5093

\begin{tabular}{l|c} 
Teacher competence & 12 \\
Learning media & 6 \\
Curriculum K13 & 23 \\
Curriculum M ultinedia & 5 \\
Computer network engineering curriculum & 7 \\
technology information & 14 \\
\hline
\end{tabular}

\section{CONCLUSION}

Based on the results of research and discussion obtained conclusions as follows . First In the overall condition of each school requires a means infrastructure that is sufficient to carry out the implementation of the training competence of teachers. Teachers require time that is free to carry out training so as not interfere with the process of learning to teach. Second of all teachers in need of training in the field of competence of each, such as in the field of engineering of computer networks, teachers require training on connecting cable fiber optics, build networks, administer the network and use mirotik and Cisco. Teachers also need the latest developments from the 2013 curriculum, namely materials , modules and teaching materials .

Related to the results of the study suggested as follows . First, complementary means of infrastructure that support to develop the competence of teachers and utilize the tools that exist and still feasible to be used in learning. Second, facilitate teachers with training that is not far from the school where the teaching that helps the cost of training and time to carry out the training. Needs of teachers are holding the training of some of the competencies of expertise in the field of each, so the need to prepare the materials of teaching as well as a module for implementing training.

\section{REFERENCES}

Dessler, Gary. 2013. Human Resource Management. (fifteenth Edition). Florida International University : Pearson

Direktorat Pembina Sekolah Menengah Kejuruan. 2008. Petunjutk teknis pelaksanaan kurikulum tingkat satuan pendidikan. Jakarta: direktorat pembina sekolah mengengah kejuruan

E Mulyasa. 2015. Kurikulum Berbasis Kompetensi, Konsep Karakteristik Implementasi Dan Inovasi. Bandung : PT. Remaja Rosdakarya

Ivanceich M. John. 2013. Human Resource Management. Twelfth Edition. :McGrawHill 
http://ijeds.ppj.unp.ac.id/index.php/IJEDS

Luh Putu Eka Diantari , et al.2018. Development of E-Module Based Mastery Learning for KKPI Class XI Subjects . National Journal of Informatics Engineering Education . DOI: http://dx.doi.org/10.23887/janapati.v7i1.12166

Marwansyah. 2014. Manajemen Sumber Daya Manusia. Bandung : ALFABETA.

Moh Fausih, Danang T. 2015. Development of E-Module Media for Productive Subjects Subject "Installation of LAN Networks (Local Area Network)" For Class X I Students of Computer Network Engineering Department at SMK Negeri 1 Labangbangkalan Madura

https://jurnalmahasiswa.unesa.ac.id/index.php/jmtp/article/view/10375/10123

Noe Raymond A. 2012. Human Resource Mangement : Gaining A Competitive Advantage. :McGrawHill

Roza Linda .dkk.2018. Interactive E-Module Development through Chemistry Magazine on Kvisoft Flipbook Maker Application for Chemistry Learning in Second Semester at Second Grade Senior High School DOI Journal of Science Learning : https://doi.org/10.17509/jsl.v2i1.12933

Sunismi and Fathani 2016 E-Module Validation Test for Calculus I Course to Optimize Student Centered Learning and Individual Learning of S-1 Students . Journal of $\begin{array}{lllll}\text { Mathematics Learning } & \text { Review } 174-191\end{array}$ https://doi.org/10.15642/jrpm.2016.1.2.174-191

Tien Amina tun, et al. 2016. Development of E-Module Based on Android Mobile Nusa Tenggara Local Ecosystem Material to Improve the Thinking Skills of High School Students . Yogyakarta. Proceedings of the National Science Education Seminar (SNPS)

Undang-Undang No 20. Tahun 2003 tentang Sistem Pendidikan Nasional Undang-Undang RI No.14 Th 2005 mengenai Guru dan Dosen 